\title{
THE NEW GENERATION OF ENGINES AND THE CHALLENGES FOR THE FOUNDRY INDUSTRY
}

\author{
W. L. Guesser ${ }^{1,2}$, L. C. Guedes ${ }^{1}$ \\ ${ }^{1}$ Tupy, ${ }^{2}$ UDESC \\ wguesser@tupy.com.br, lcguedes@tupy.com.br
}

\begin{abstract}
Examples of the new generation of automotive engines, with emphasis on engines with cylinder blocks in cast iron are presented. It is discussed the new grades of cast iron, with high strength, gray and compacted graphite iron, and their properties. It is review the development of process to produce complex and lightweight cylinder blocks, with the challenges for the foundry industry. A comparison between engines with aluminum and cast iron blocks will close the discussion.
\end{abstract}

\section{INTRODUCTION}

The growing environmental and fuel consumption requirements has brought new challenges for the designers and manufacturers of internal combustion engines. Figure 1 shows the response of the automotive industry to these requirements, reducing fuel consumption, between 1980 and 2014, on 33\% for passenger cars and 30\% for light trucks [1]. This reduction in fuel consumption is based on a large number of innovations in the vehicle, with the weight reduction of the components being an important tool. In a passenger car engine, the cylinder block is about $27 \%$ of the engine weight [2], so that many studies concerning this component were carried out. However analysis of individual components do not carry all the weight reduction potential. The downsizing approach, aiming to reduce the engine size, brings weight reductions for a large set of components, resulting in a compact and lightweight engine. Figure 2 shows the reduction of the engine size, for a $100 \mathrm{~kW}(135 \mathrm{HP})$ gasoline engine in Germany [3]. This reduction brought huge increases in requests on the engine block, both thermal and mechanical, and cast irons represent the natural solution for this new generation of engines, given its strength reserve.

The purpose of this work is to present and discuss the results of modern engines, designed with an emphasis on downsizing, and how these new technologies requires developments in the foundry industry.

\section{COMPACT AND LIGTHWEIGTH ENGINES}

The first illustration of downsizing is the recent series of 3 cylinders engines, launch mainly in Europe. A good example is the Ford 1.0 L 3 cyl Ecoboost (figure 3). It is a gasoline engine, with turbocharged versions, with the following characteristics [4]: 
- $74 \mathrm{~kW}(99 \mathrm{HP})$

- 88-92 kW (118-123 HP). 170-200 N.m (125-148 ft.lb)

There is an additional version, for the Fiesta Red and Black Editions, with $103 \mathrm{~kW}$ (138 HP) and torque of 210 N.m (155 ft.lb).

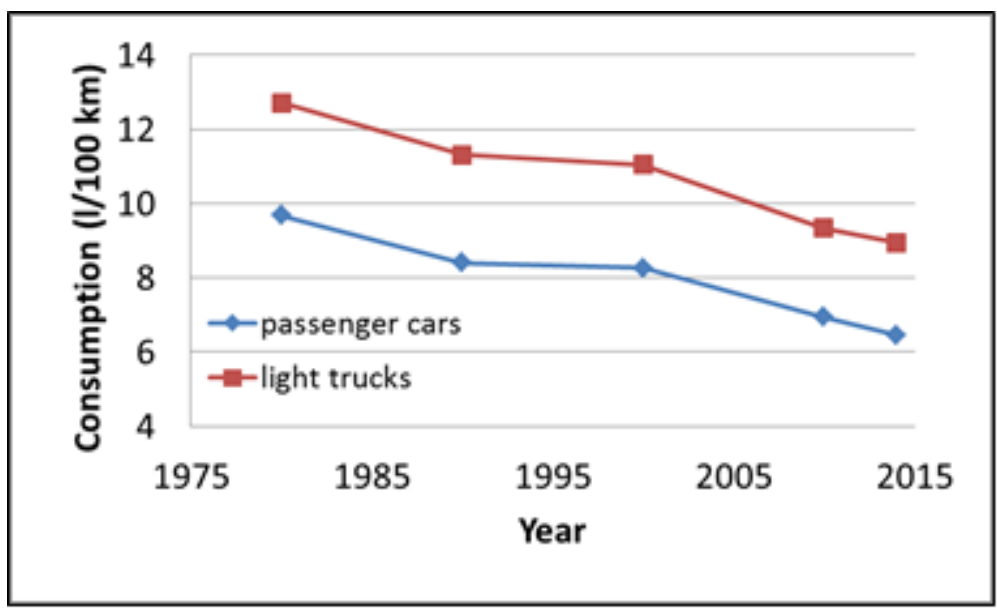

Figure 1 - Fuel economy performance of passenger cars and light trucks in USA. NHTSA [1]

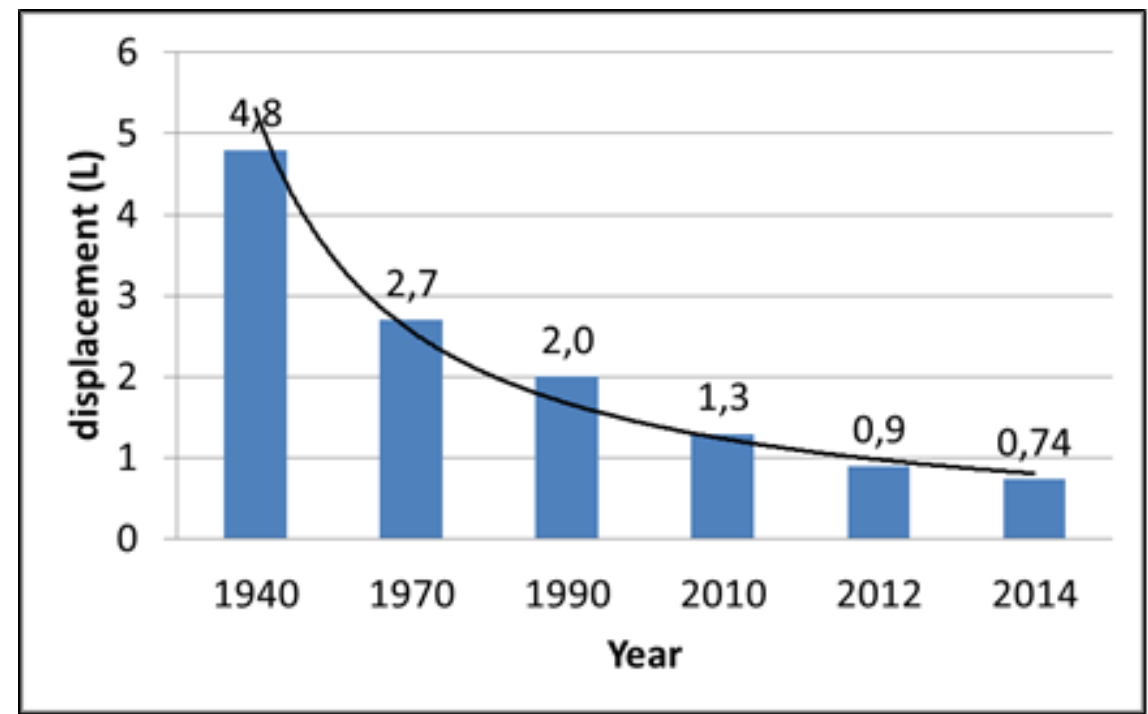

Figure 2 - Displacement evolution for gasoline engines with $100 \mathrm{~kW}$ (135 HP) in Germany [3].

The cylinder block is in Gray Iron grade 250. It provides up to 50\% faster warm-up than aluminum cylinder block. The engine block has the size of an A4 sheet of paper. The flywheel has been deliberately unbalanced to ensure smooth running, without the use of energy sapping balance shafts. The exhaust manifold is cast into the aluminum cylinder head, reducing warm up times. The engine weight is $97 \mathrm{~kg}$ [4]. 
This engine received many international awards, like the 2012 Best New Engine and the International Engine of the Year (Sub 1-litre) for 2012-2013-2014-2015 [5, 6].

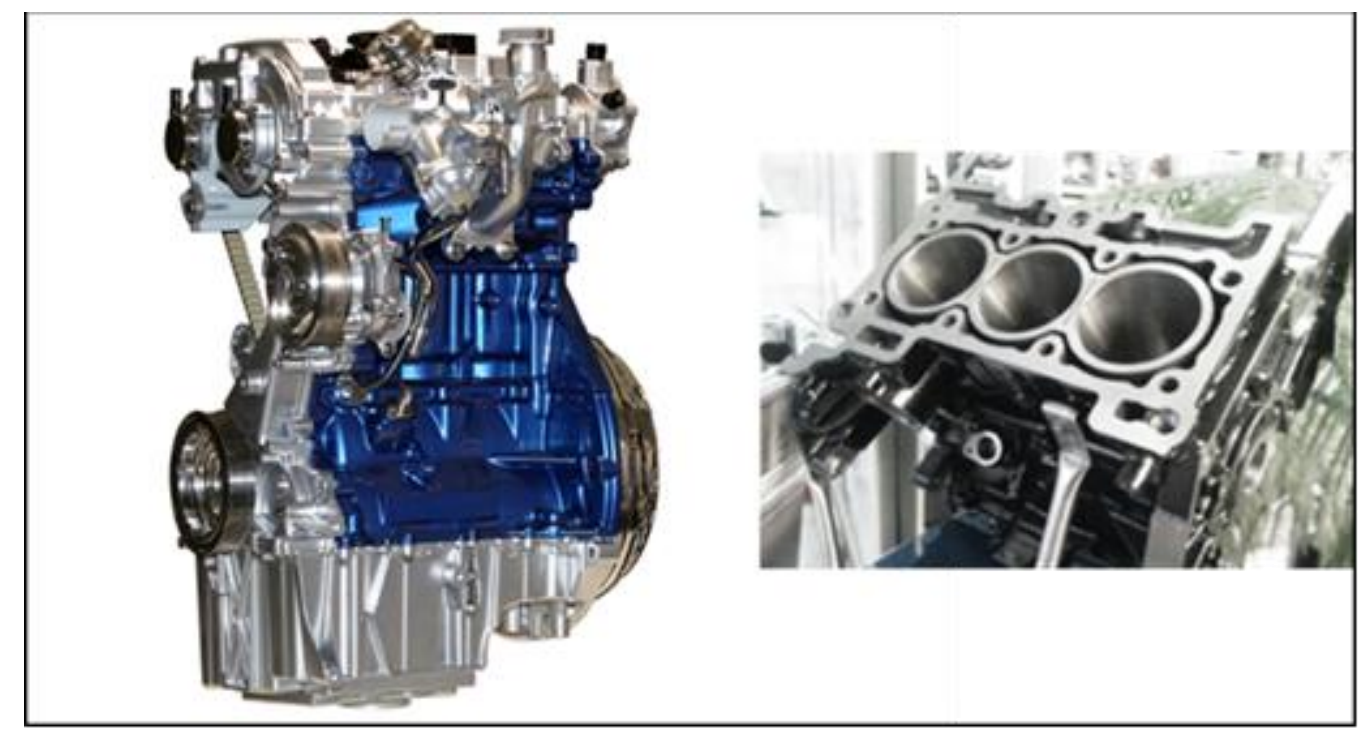

Figure 3 - Ford Ecoboost. 1,0 L, with 3 cylinders. 2012 Best New Engine. 2012-2013-20142015 International Engine of the Year [4].

Figure 4 shows a high performance 3,0 L V6 diesel engine, from VM Motori (630 DOHC), with 160-200 kW (240-270 HP), 570-600 Nm torque. The design of this engine requires a high strength material for the cylinder block, so the decision lies on Compacted Graphite Iron grade 450 , for the cylinder block $(72 \mathrm{~kg})$ and for the bed plate $(16 \mathrm{~kg})$. This engine meets the Euro 5+ standards, and team the following vehicles: Maserati Quattroporte and Ghibli VI III, and Jeep Grand Cherokee. Engine weight: $220 \mathrm{~kg}$. The VM 3.0L was considered in 2014 one of the 10 best engines in the North American marketplace by Ward's Auto. The contest, extensive and qualified, involved 44 different vehicles and powertrain of any kind from gasoline to diesel and electric [7].

Another example is the Audi V6 3,0 L TDI (figure 5), diesel, Euro 6. It is used for Audi B7 A4, Audi C6 A6, Audi D3 A8, Audi Q7, Volkswagen Phaeton. There are 2 versions: $160 \mathrm{~kW}$ (215 HP) and $200 \mathrm{~kW}$ (272 HP), up to $600 \mathrm{Nm}$ (442.5 lb.ft) of torque. The engine weight is $219 \mathrm{~kg}$. The cylinder block is in CGI 450. Thanks to its high strength, the crankcase of compacted graphite iron permits low wall thicknesses. That alone saved the development engineers eight kilograms of weight. Another features: UV laser-honed exposed bores, watercooled exhaust gas recirculation (EGR), catalytic converter and diesel particulate filter (DPF) [8]. 


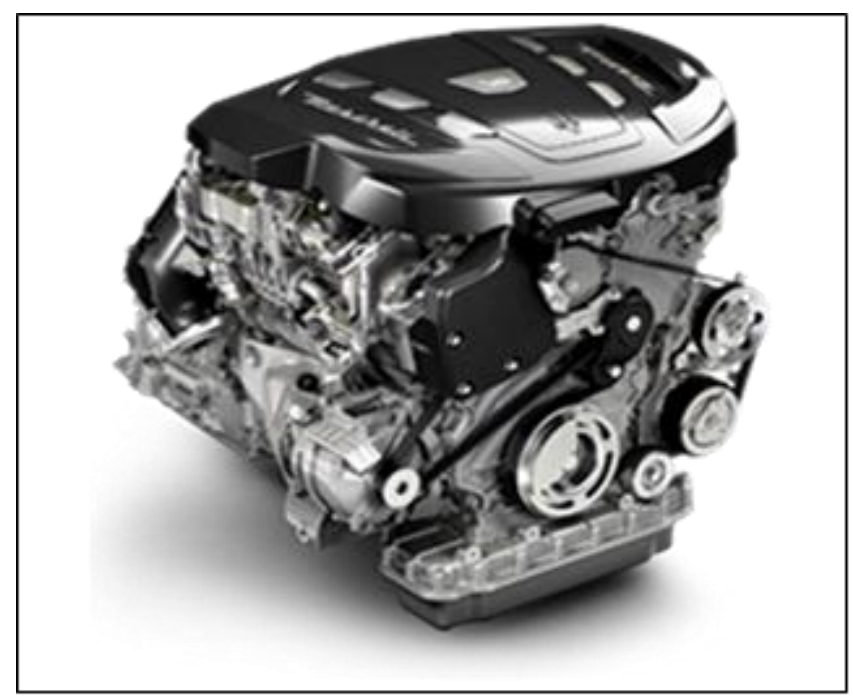

Figure 4 - VM Motori V6 3.0 L diesel engine, with 160-200 kW (240-270 HP) (630 DOC). Cylinder block and bed plate in CGI 450. Engine size: 695-729-698 mm, weight of $220 \mathrm{~kg}$. [7].

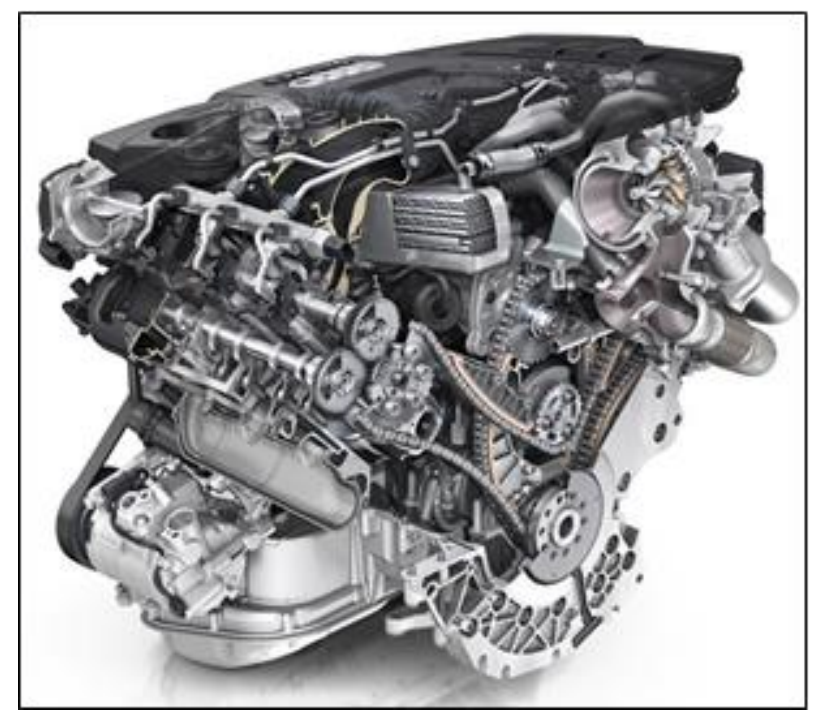

Figure 5 - Audi V6 3,0 L TDI. Diesel, Euro 6. Length of $444 \mathrm{~mm}$, weight of $219 \mathrm{~kg}$ [8].

Other example is presented on figure 6, the Audi EA888, I4 1,8/2,0 L engine, gasoline, turbo, with direct injection $[9,10]$. Power and torque are168 kW (225 HP) and 350 N.m (258 lb.ft). The engine weights $132 \mathrm{~kg}$; the cylinder block, with $33 \mathrm{~kg}$, is in gray iron grade 250, with 88 $\mathrm{mm}$ of cylinder spacing and external walls down to $3,0 \mathrm{~mm}$. The crankshaft is dieforged steel, the cylinder head is aluminum and the exhaust manifold is cast iron, with integrated turbocharger. Applications: Audi 2.0 L TFSI A4/A5/Q5/VW Golf GTI [9, 10]. It was the winner of the "1.8-litre 2.0-litre" category in the 2009 annual competition for International Engine of the Year [6]. 


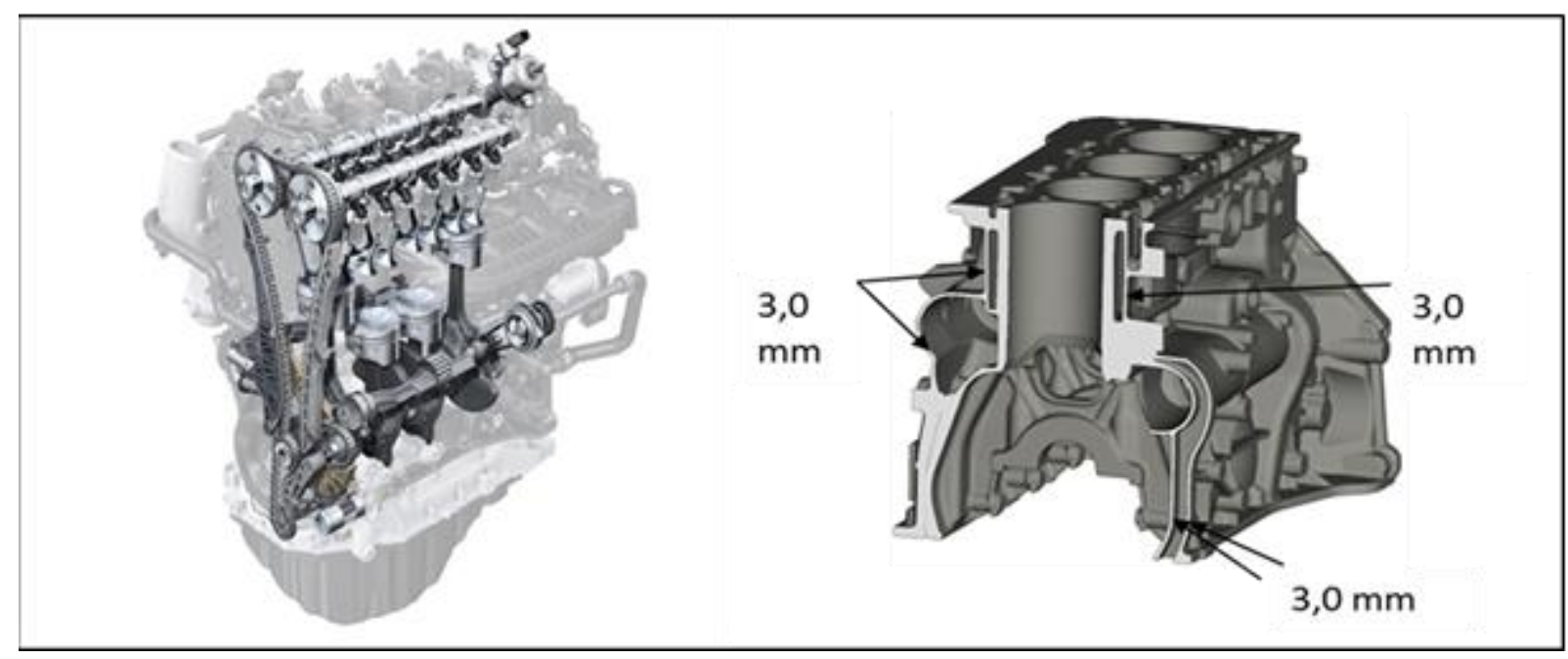

Figure 6 - Audi 1.8/2.0 R4 16v TSI/TFSI (EA888) [9].

One of the latest developments is the Ford EcoBoost 2.7L V-6 (figure 7), a gasoline engine with innovative concepts, used in the F150 pickup. This is the first petrol engine in USA with engine block in CGI. It is also the industry's smallest engine in a full-sized truck.

The 2.7L EcoBoost V6 engine has the following characteristics [11]:

- V6 2.7 L, gasoline

- Direct injection

- $239 \mathrm{~kW}$ (320 HP) and 502 N.m (370 lb.ft) at $2500 \mathrm{rpm}$.

- Twin Turbo

- Cylinder block in CGI 450, cylinder heads in aluminum.

- Bearing caps casted integrated with the cylinder block and fractured.

- Application: SUV, with consumption of $9.8 \mathrm{~km} / \mathrm{l}(23 \mathrm{mpg})$

The lineless cylinder block is produced in compacted graphite iron (CGI), Ford's first application of this material in a gasoline engine. Its "composite" architecture with separate CGI cylinder block and die-cast aluminum ladder frame is a breakthrough concept, figure 8 [12]. The upper part is in CGI, and includes the cylinder and the main bearing caps. The bearing caps are cast integrated in the cylinder block and subsequently fractured, using laser etching. After the crankshaft assembling, these fractured surfaces result in additional engine stability. To reduce weight to the bottom the lower ladder frame is die cast aluminum (B, fig 8) and bolts onto the CGI upper half (A, fig 8) [13]. Thus, the cylinder block structure is guaranteed by CGI, which provides high fatigue strength and rigidity, while the non-structural parts are produced in aluminum alloy, with low density. This combination of materials, combining properties, made it possible to reach high performance with low weight. 


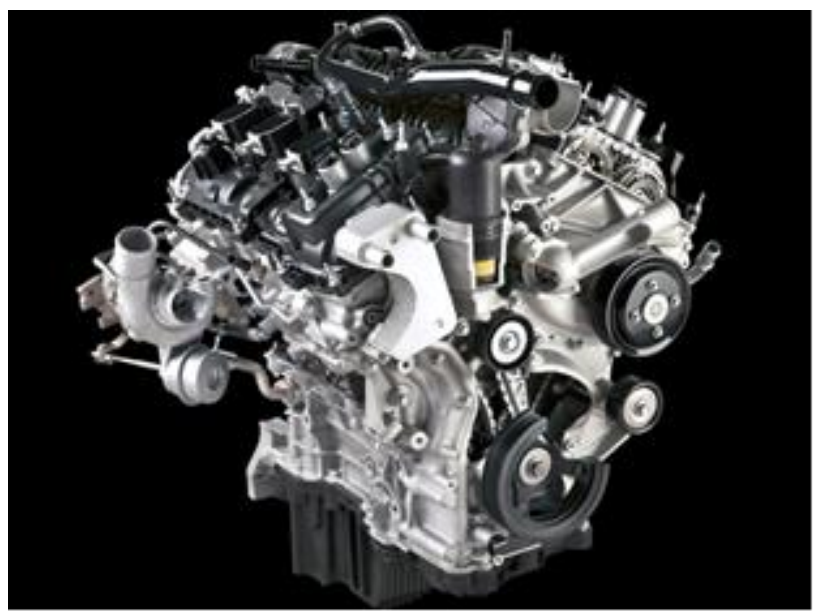

Figure 7 - Ford Nano. Engine V6 2.7 L, gasoline, 239 kW (320 HP) and 502 N.m (370 lb.ft). Bi turbo [11].

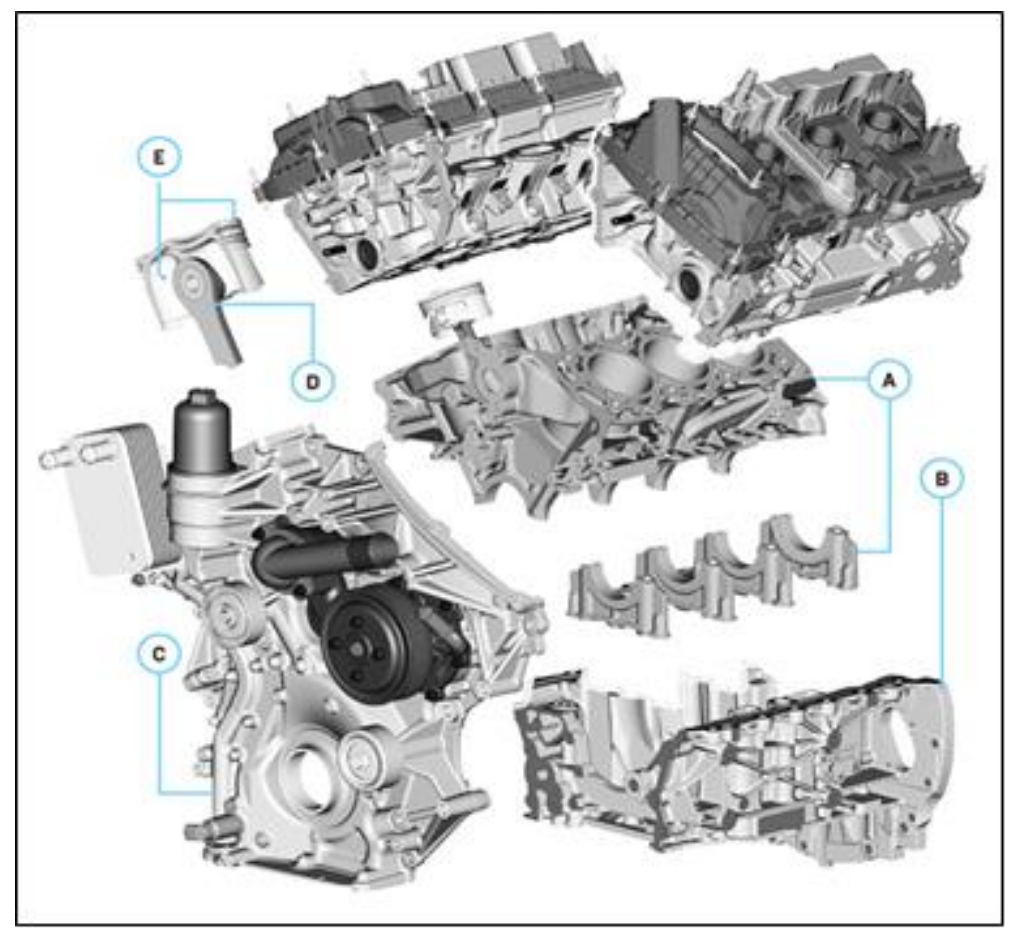

Figure 8 - Ford Nano V6 engine concept [13].

In all these examples of new engines, cast iron is used for the cylinder block, due to its high strength, making possible to extend the application of the engines for many different areas.

It follows a discussion about the important properties of the high strength grades of cast irons used for cylinder blocks. 


\section{PROPERTIES OF HIGH STRENGTH CAST IRONS FOR CYLINDER BLOCKS AND HEADS}

The first property to be considered, concerning the design of cylinder blocks and heads, is strength. As in all cast alloys, the strength depends on the cooling rate during solidification, i. e, from the section thickness of the part. As the section thickness increases, the strength decreases, due to coarsening of the microstructure. This happens with all cast irons, gray and CGI. Figure 9 shows an example for a V6 cylinder block, in CGI grade 450. The specification of UTS min $450 \mathrm{MPa}$ and max $20 \%$ nodularity is set for the main bearing, the thickest section of this part. In other places, with high solidification rates, the nodularity and UTS are higher, and this variation can be used advantageously in the design of the part (figure 10).

Fatigue strength is the main property in the design of a cylinder block, and cast irons provide very good values for this property. Figure 11 shows results for gray iron and for CGI, in standard samples and in the main bearing of cylinder blocks. Endurance ratio (fatigue strength/UTS) of 0,29 are typical of good quality gray iron grade 300 (ISO Standard set an endurance ratio of 0,25 ). For CGI, an endurance ratio of 0,38 is typical, and this is the result of the metallurgical modification in the graphite, with compact or wormlike shape, instead of graphite flakes as in gray iron [15].

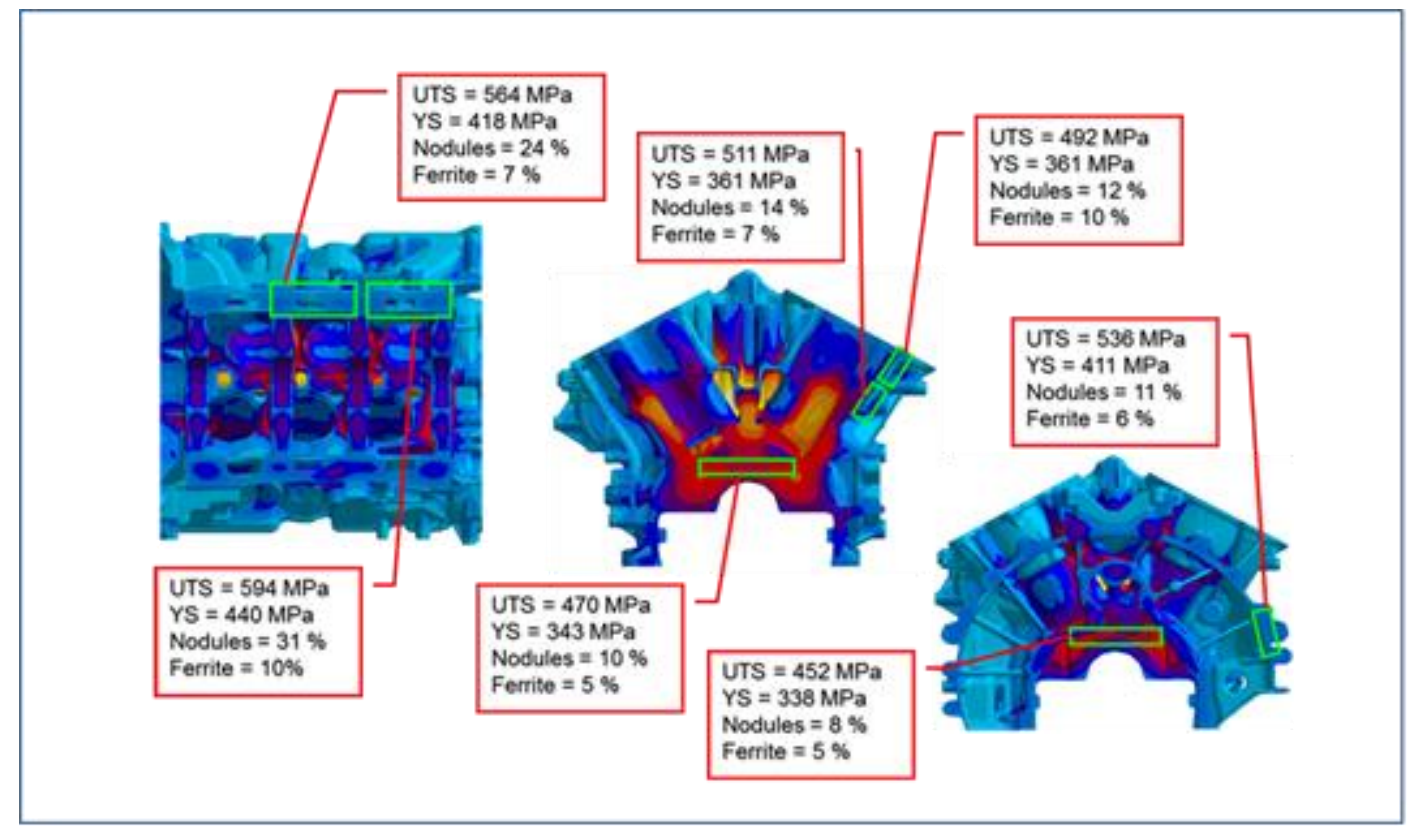

Figure 9 - Microstructure and mechanical properties of a V6 cylinder block, 2.7L CGI 450. The UTS min of $450 \mathrm{MPa}$ is specified for the main bearing. 

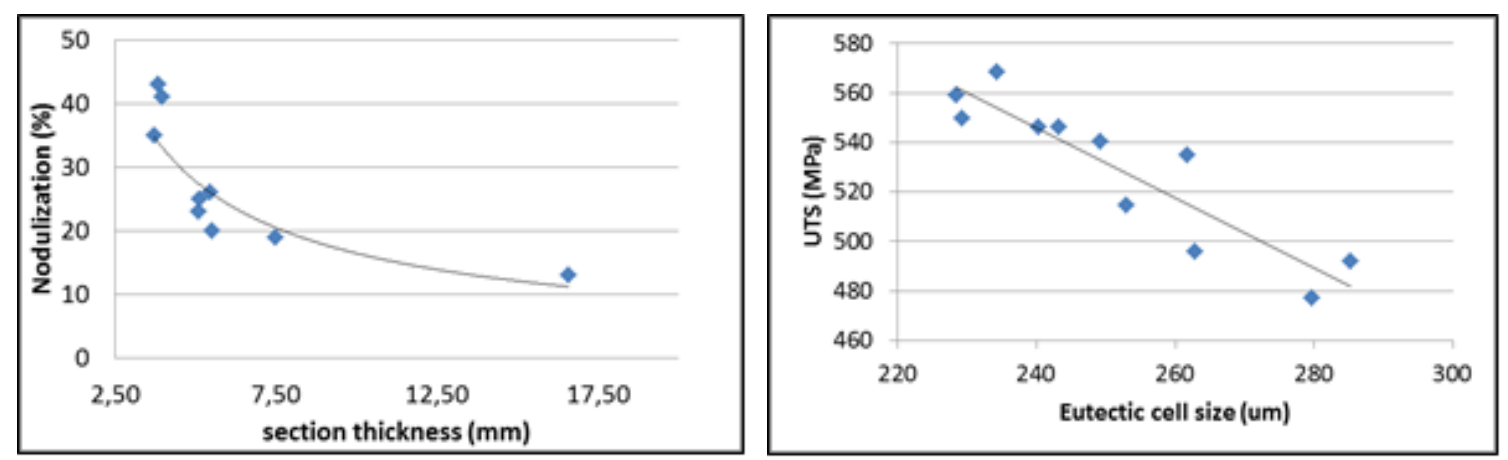

Figure 10 - Results of thin sections cylinder blocks in CGI 450. Increased tensile strength due to higher nodulization and lower size of the eutectic cell [14].

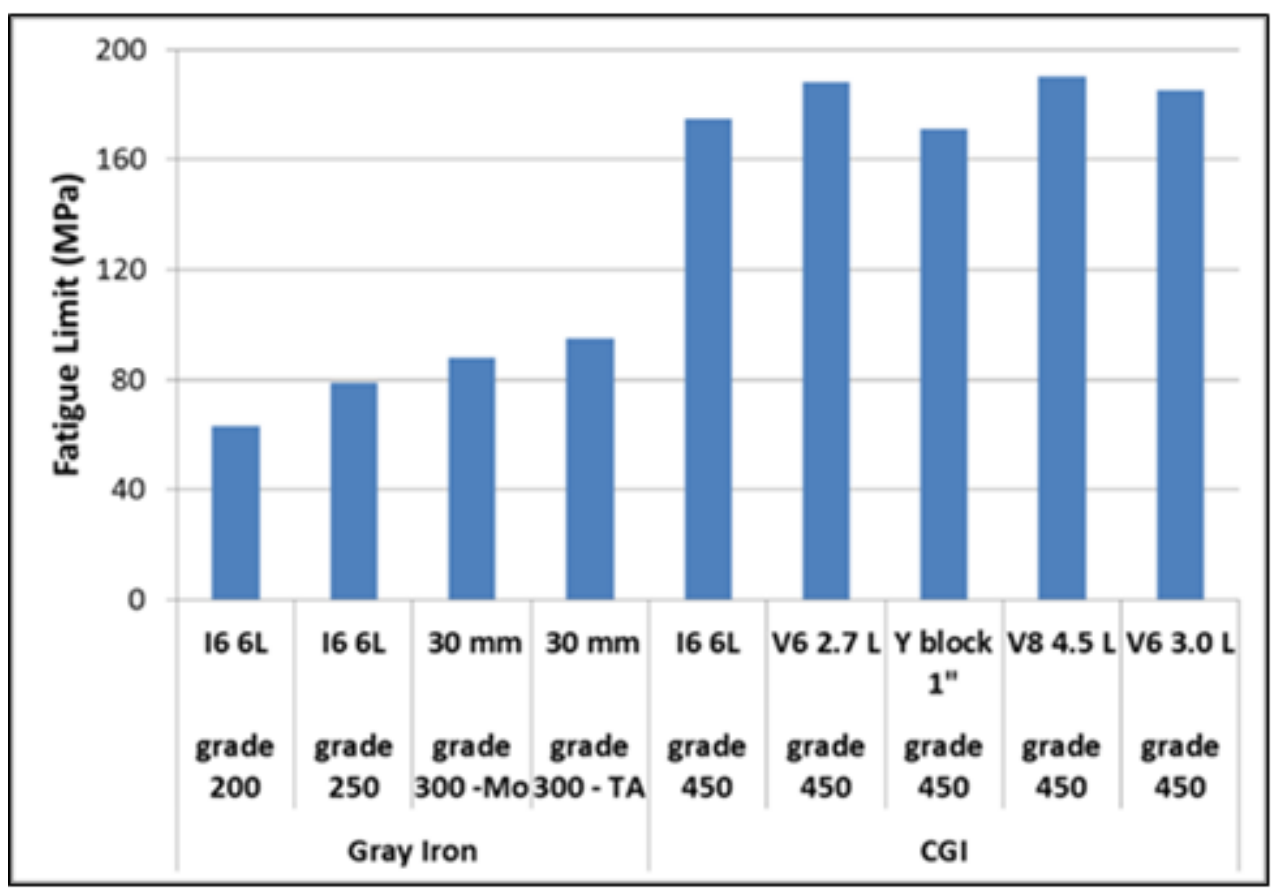

Figure 11 - Push-pull fatigue results for gray irons and CGI Grade 450. Results from standard samples and from cylinder blocks [15].

Another important property for engine blocks and heads is the elastic modulus. This property measures the stiffness of the material, and for cylinder blocks, it will maintain the shape of the cylinder during operation. Oil consumption is affected by the elastic modulus of the material used for the construction of the cylinder block. As can be seen in Figure 12, CGI is distinguished by high values of elastic modulus, thus maintaining the cylinder shape even under high stresses, and so minimizing the oil consumption and emissions [16].

In the resonant test to measure the elastic modulus, it is also possible to characterize the capacity of vibration absorption, the damping capacity. Gray irons present a high damping capacity (figure 12), and this property can be used to design a quiet and strong engine cylinder block [16]. 


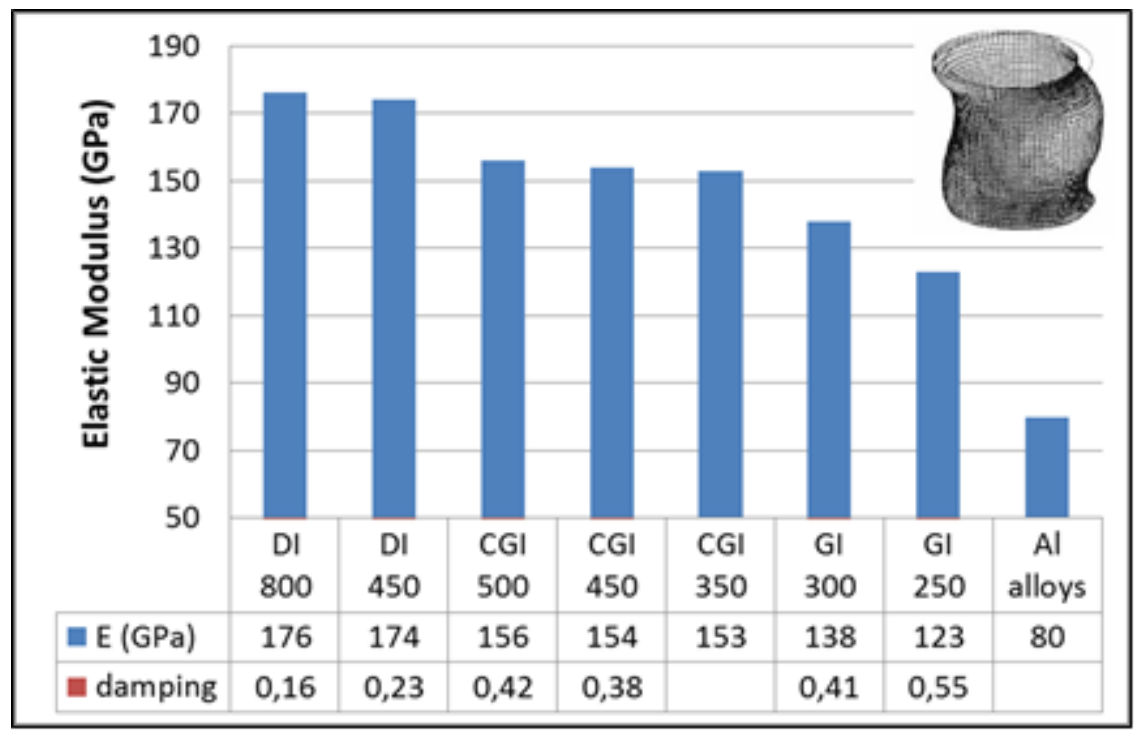

Figure 12 - Elastic modulus and damping capacity of cast irons and aluminum. Resonant frequency [16].

For cylinder heads, additional points must be considered, concerning the properties of the materials: hot strength and thermal conductivity. Figure 13 shows some results on hot strength for Mo alloyed gray iron. For cast irons up to $350^{\circ} \mathrm{C}$, the decrease on tensile strength is very low [17]. Results on thermal conductivity for different grades of cast iron, gray and CGI, can be seen on figure 14. Graphite plays an important role on thermal conductivity, so the highest thermal conductivity results are obtained with gray iron, with flake graphite, and with low amount of alloying elements (grade 250). In gray iron there is a tendency of decreasing thermal conductivity as the temperature increases. This is not observed in CGI, so at $400^{\circ} \mathrm{C}$ the difference between the different types of cast irons is reduced [18].

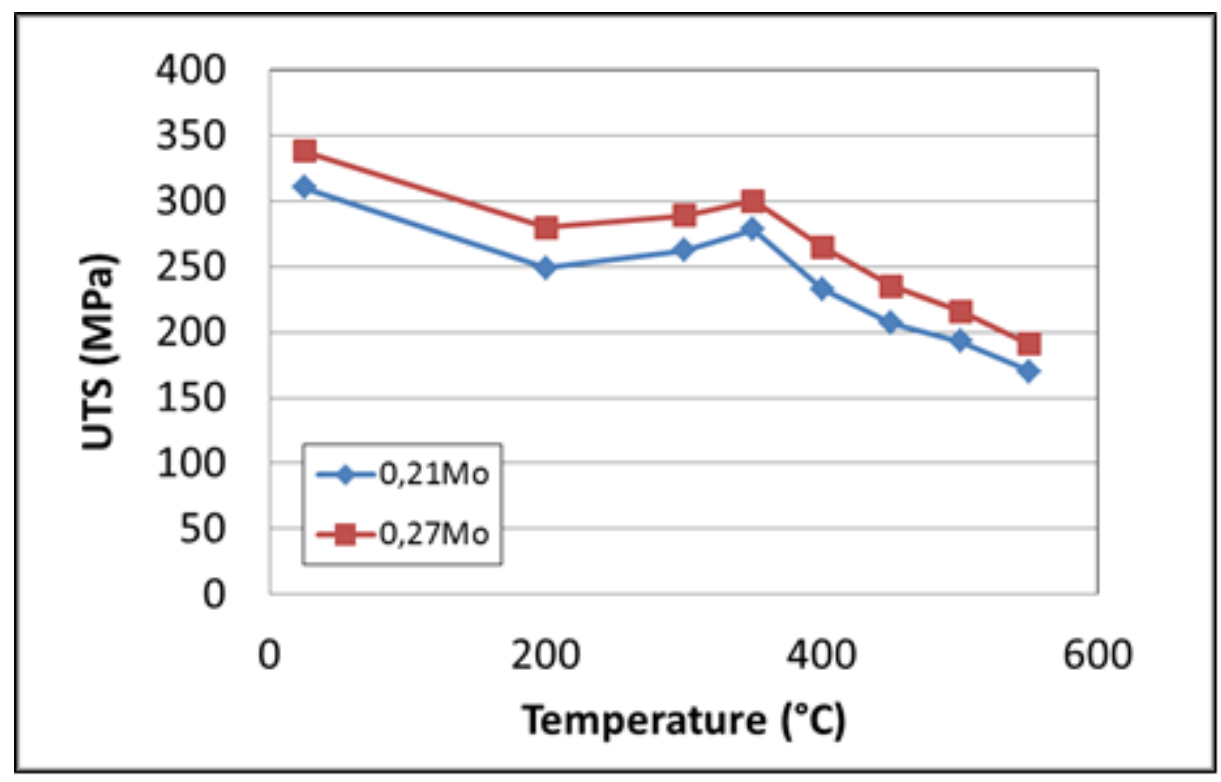

Figure 13 - The strength of cast iron remain stable up to $350^{\circ} \mathrm{C}$ [17] 


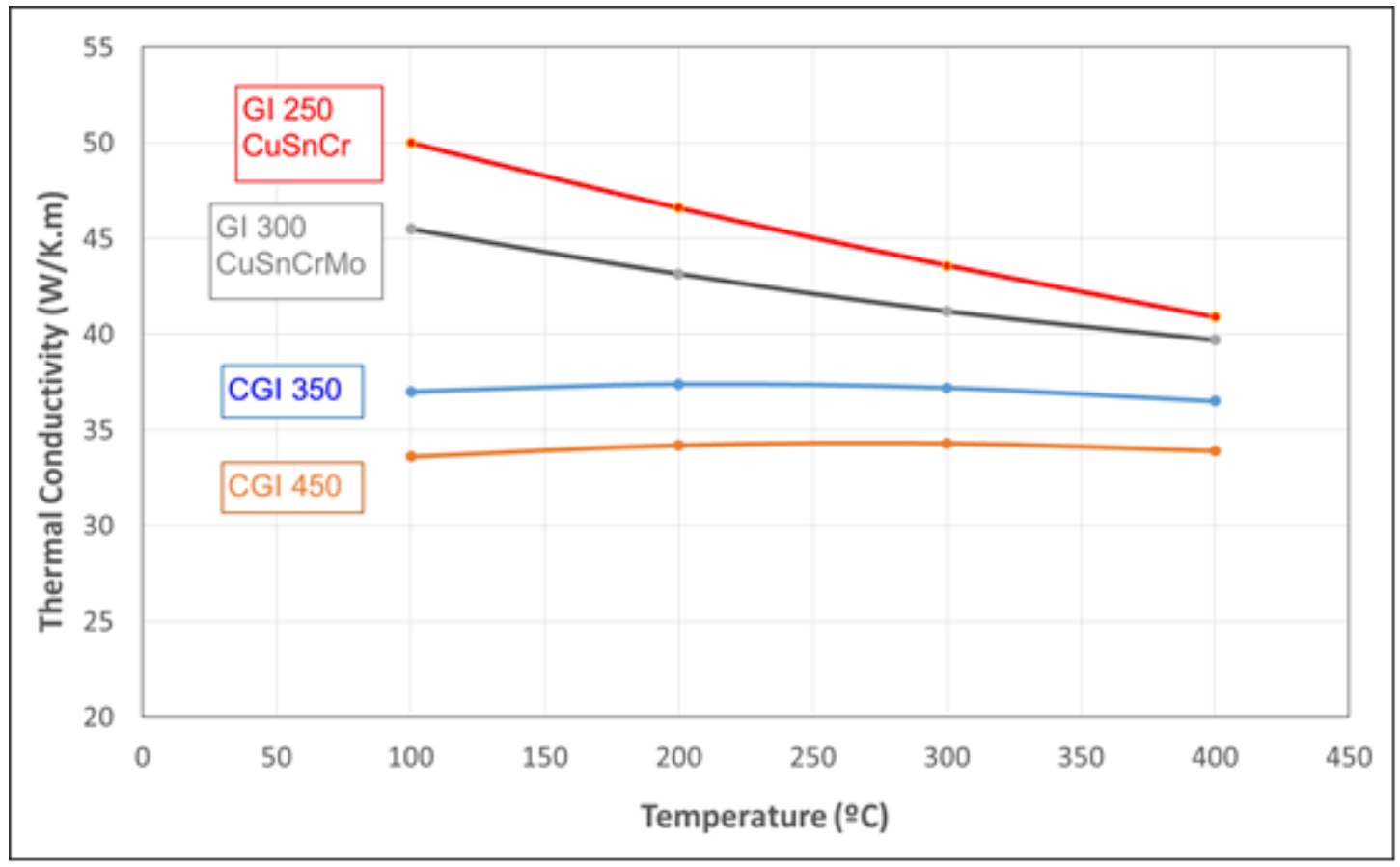

Figure 14 - Thermal conductivity of gray irons and CGI [18].

Additionally, engine blocks are subject to wear conditions due to the movement of the piston/ring on the cylinder. To prevent wear, the cylinders undergo a special machining process, called honing, which aims to create a network of grooves for retention and distribution of lubricant (figure 15). Thus it is important that such grooves maintain uniformity, whether in relation to the depth, width, distance between themselves and in relation to the crossing angle and parallelism. The ideal condition is one in which all grooves are parallel to each other, depending on the specification of the crossing angle, as illustrated in figure 15 [19]. Furthermore, during machining occurs breakage and removal of graphite particles near the surface, it is desirable that these cavities remain open and are not covered by deformation of the matrix, so that they can act as a lubricant retention sites [20]. Different honing processes lead to reduced wear, as honing plateau (removal of surface peaks), burnishing with slip ("honing slide"), and burnishing with helical slide ("helical slide honing") [20]. For CGI engine blocks, laser texture generation is used in the pre-honed cylinder (with fine honing). This process is associated with the introduction of nitrogen, forming iron nitrides near the surface, which greatly reduces the coefficient of friction [20]. Table I shows results of oil consumption and wear with different honing processes, highlighting the honing process with helical sliding and plasma [20].

The use of CGI in engine blocks allows the use of the process of fracture of the bearing caps, which are then casted integrated in the engine block [21]. With CGI grades 450 and 500, the fracture occurs in only one plane, with no macroscopic plastic deformation, which allows the subsequent assembling of the caps on the fracture itself (figure 16). This arrangement restricts lateral movement between the bearing cap and the block, increasing the system's stiffness [22]. 


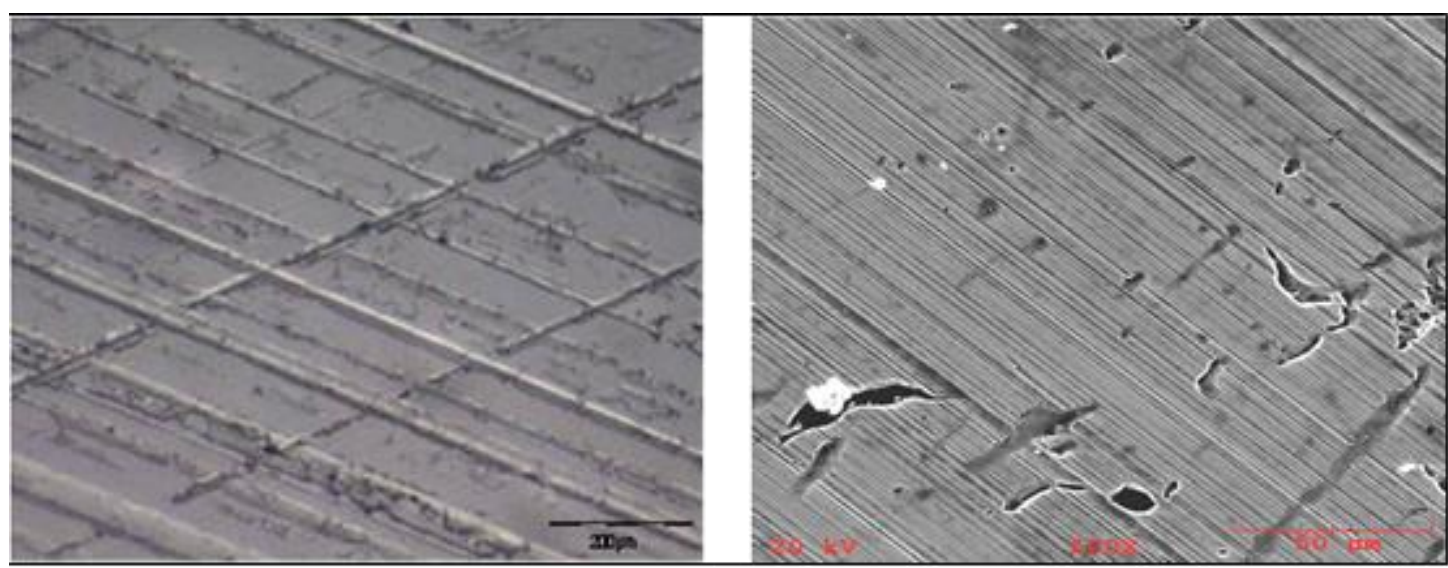

Figure 15 - Surface of cylinder bores of gray iron (plateau honing) and CGI (laser honing) [19].

Table I - Wear and oil consumption for different honing processes. Cylinder block of gray iron [20].

\begin{tabular}{|l|c|c|c|c|}
\hline & \multicolumn{4}{|c|}{ Honing process } \\
\cline { 2 - 5 } & $\begin{array}{c}\text { Conventional } \\
\text { 1st ring CKS }\end{array}$ & Plato & $\begin{array}{c}\text { Helical slide } \\
\text { 1st ring CKS }\end{array}$ & $\begin{array}{c}\text { Plasma } \\
\text { 1st ring GDC50 }\end{array}$ \\
\hline Oil consumption (g/h) & 55 & 52 & 19,7 & 11,5 \\
\hline Oil consumption (g/kWh) & 0,17 & 0,16 & 0,06 & 0,04 \\
$\begin{array}{l}\text { Oil consumption (\% of the fuel } \\
\text { consumption) }\end{array}$ & 0,08 & 0,08 & 0,03 & 0,02 \\
$\begin{array}{l}\text { Wear of the 1st ring (nm/h) } \\
\text { Wear of the cylinder (nm/h) }\end{array}$ & 8,5 & - & 4 & 0,83 \\
\hline
\end{tabular}

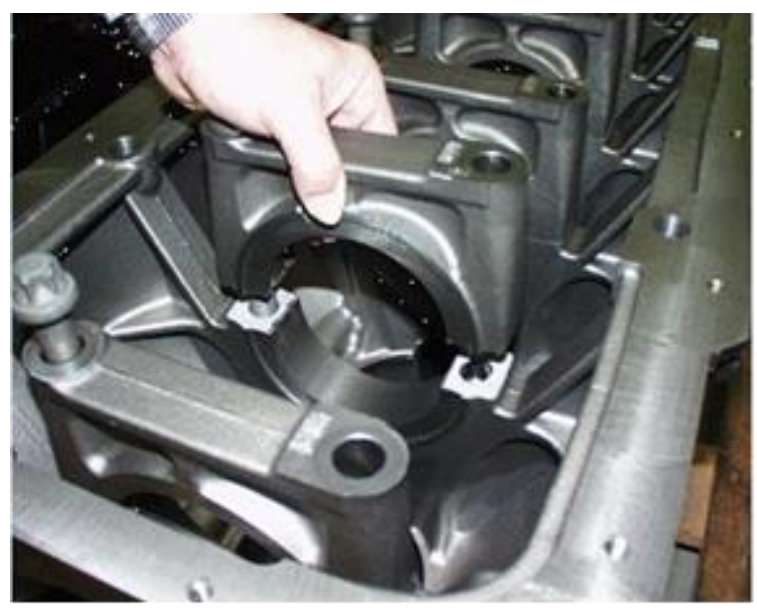

Figure 16 - Fracture of bearing caps. Increasing stiffness of the engine. 


\section{THE PRODUCTION OF MODERN CYLINDER BLOCKS}

The design of thin wall cylinder blocks is based on some concepts that brings a lot of challenges for the foundry industry. Today the wall thickness can be as low as 3,0 mm, with a trend to reduce this number to $2,7 \mathrm{~mm}$ or even to $2,5 \mathrm{~mm}$. At the same time, the wall thickness variation is set today on $0,5 \mathrm{~mm}$. Also several functions are integrated in the engine block.

The casting process was then changed to meet these new demands. For example, the cylinder block is made totally into a core package, instead of laying the core package into a green sand mold, for better dimensional accuracy. The design of the cores is made considering that the core package is assembled prior washing, in order to avoid having a coating between the cores. Figure 17 shows the concept of pouring cylinder blocks in vertical position, with the part completely inside the core package. The final assembling of the core package is done in the core room, prior the painting of the core package. This process also reduce the risk of sand inclusions and reduce the wall thickness variation. With the symmetrical filling of the mold, it is reduced the thermal load (during filling the mold) for critical cores, like water jacket and oil channels. This technology brings also less turbulence on the filling of the mold cavity and better chance to gas removal of the cores. Additionally, for CGI, where sometimes the use of risers is a must, it allows the use of feeders on the top deck, a critical position for cylinder head screw positions.
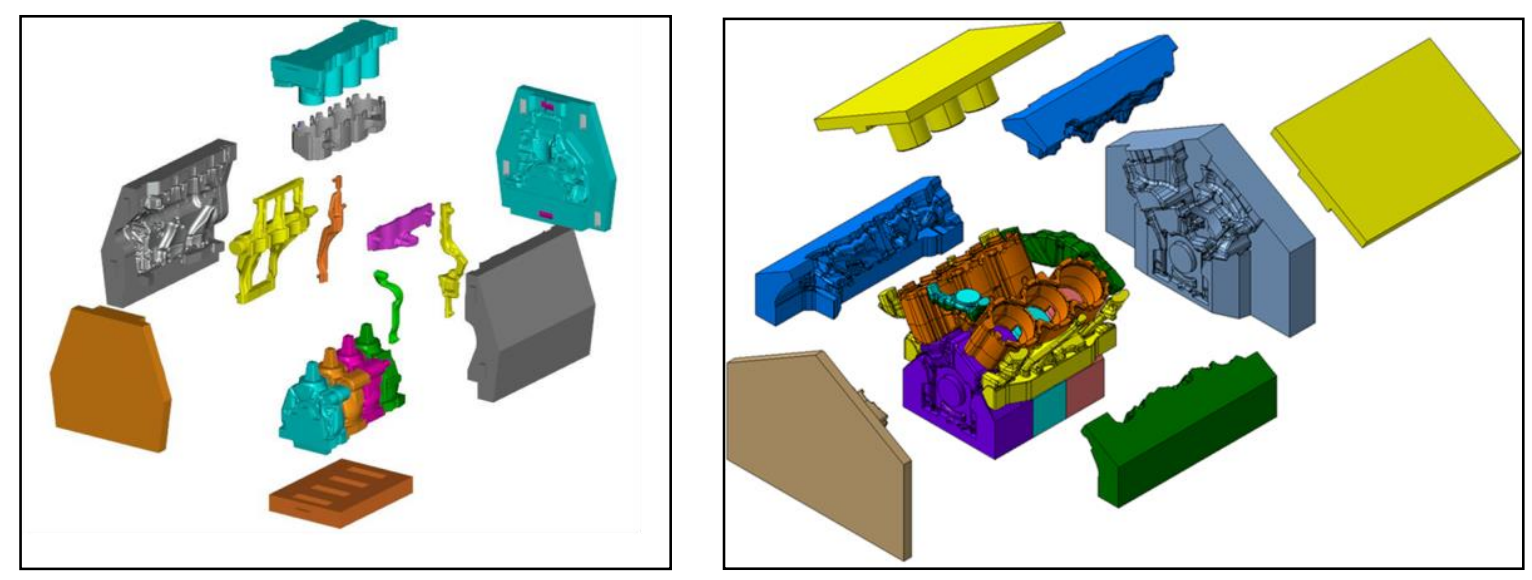

Figure 17 - Core package for casting cylinder blocks in vertical position. (a) I4; (b) V6.

For some cores, the use of special sands and coatings can be a solution to avoid deformation and finishing problems. Alternative to silica, some special sands can be: bauxite, synthetic ceramic products, chromite, zircon sand. Figures 18 and 19 shows some results of thermal expansion of base sands, and the effects on deformation of a critical core [23]. Also the use of special core coatings is considered, to control the heat flow and to reduce interactions of the metal surface with the mold, especially with CGI cylinder blocks. 


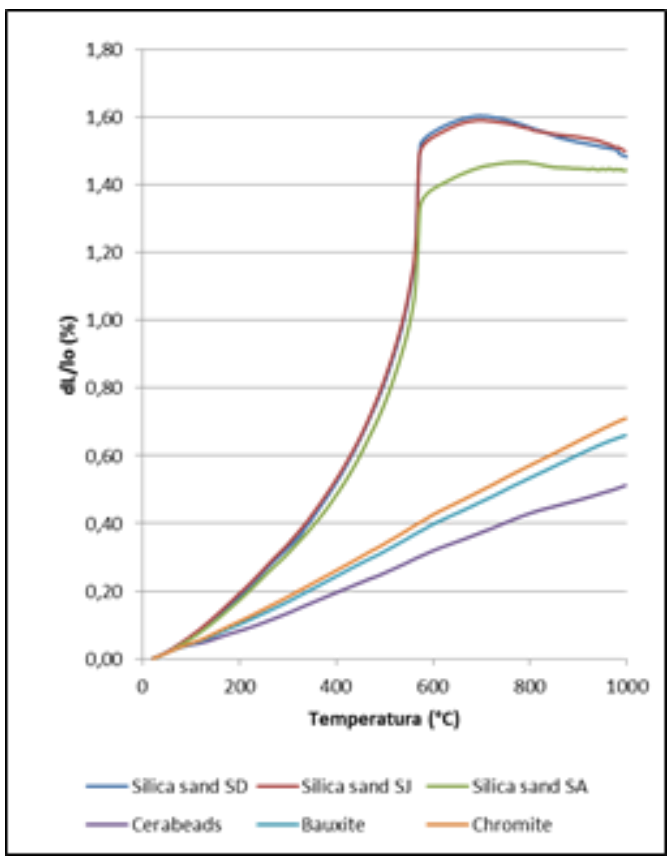

Figure 18 - Expansion of base sands and additives [23].
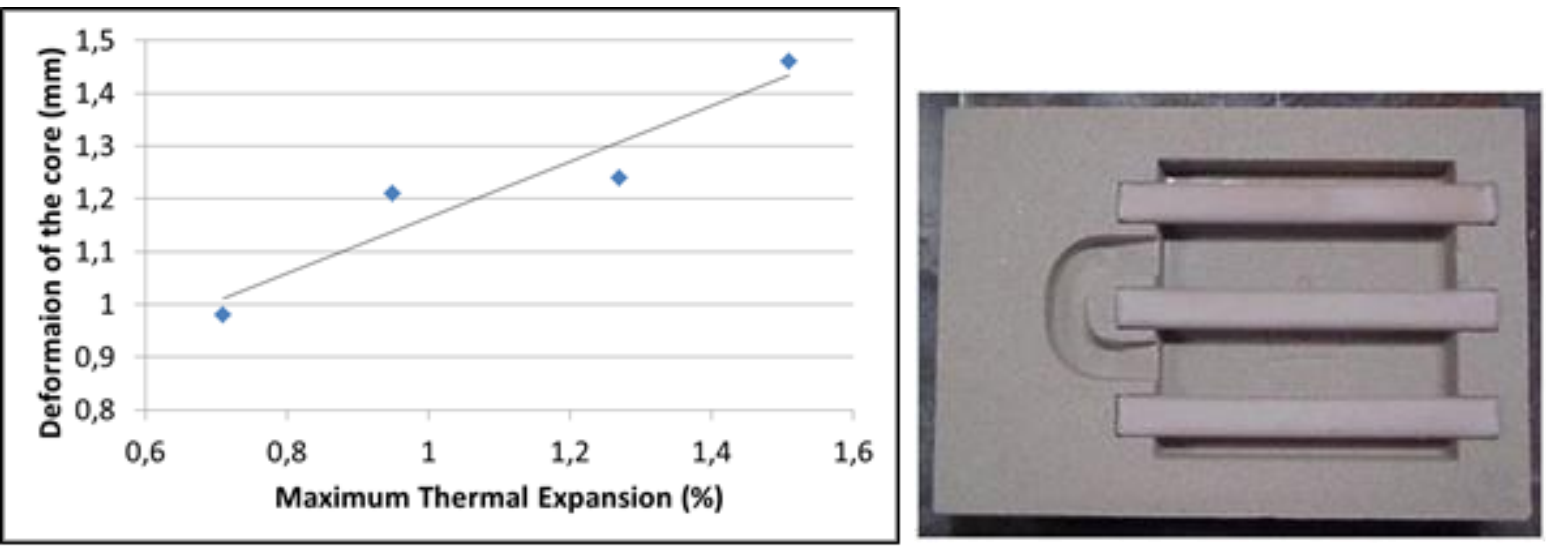

Figure 19 - Relation between the maximum thermal expansion of the base sand (dilatometer test) and the deformation of the core (foundry test, on the right). The maximum thermal expansion was changed by mixing silica and chromite sands (0-30-70-100\%) [23].

Additional points:

- automation of the core room and of the finishing room, looking for quality and consistency.

- controlling the metal at the pouring station with thermal analysis to select the right inoculation amount. The goal is to have a cast iron with small eutectic cells, with high strength, but at the same time, to avoid carbides and shrinkage porosities.

A critical point is the build-up of residual stresses on thin-wall cylinder blocks for high power engines. In this case, thin sections are associated with a strong structure (to withstand the high stresses), and this design can lead to high residual stresses. It is very important to control the 
shakeout time, and in some cases it is necessary to optimize the in-mold cooling time for each casting. The results of figure 20 are connected to a development where the molding line was redesign for a specific cylinder block.

With the same goal, the shot blasting is done with steel particles of limited kinetic energy, in order to avoid the buildup of residual stresses in this operation. Automation is also a must for quality (low residuals on internal cavities) and consistency (figure 21).

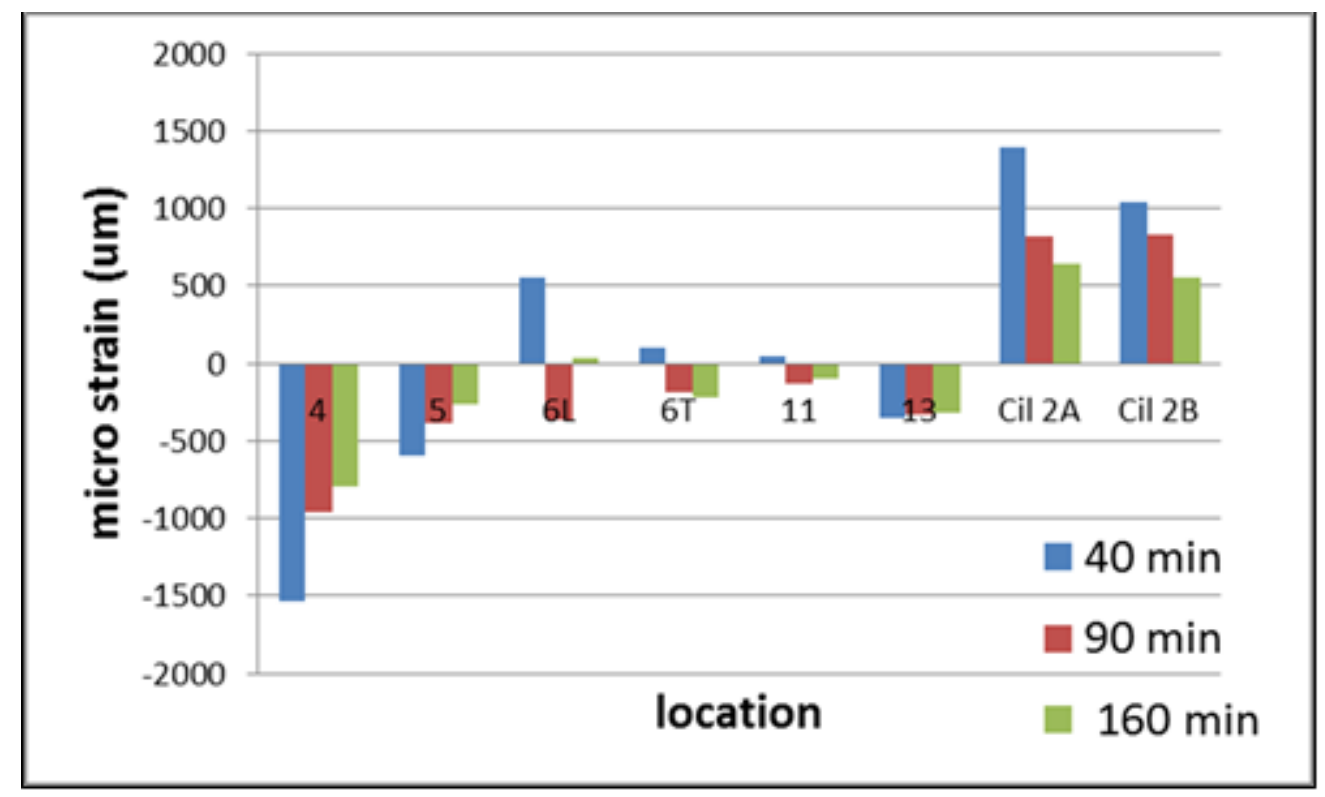

Figure 20 - Residual stresses and in-mold cooling time. I4 cylinder block. Residual stresses measurements in different locations on the part. As a general trend, external areas are with compressions stresses and internal areas with tensile stresses.

\section{CAST IRONS AND ALUMINUM ALLOYS FOR CYLINDER BLOCKS AND HEADS}

Figure 22 compare some important properties when selecting a material for cylinder block or head. The outstanding properties of aluminum alloys are the low density and the high thermal conductivity, so this is the preferred material for automotive cylinder heads. On the other hand, fatigue strength, stiffness and damping capacity are much higher with cast irons, and this family of materials show stable strength up to $400^{\circ} \mathrm{C}$ (figure 23). This allows the design of downsized engines with cylinder block in cast iron, with final weight even lower than those with aluminum cylinder blocks. We are going to see some examples.

Figure 24 shows two cylinder blocks from the same OEM. The engines have the same power, and the change was from a V6 3,0 L engine, with an aluminum cylinder block, to an I4 2,0 L engine, with gray iron cylinder block. Due to the higher strength of cast iron, the power density was increased from $71 \mathrm{~kW} / 1$ to $110 \mathrm{~kW} / \mathrm{l}$. The 4-cyl engine is a concept of global engine. Since cast iron has power reserve, 6 different engines are produced with this cylinder block, with power from 85 to $220 \mathrm{~kW}$. The volume reduction involves reducing the weight of various components, e.g. the crankshaft [27]. This is an example of downsizing, with reduction of the engine volume and increased efficiency. 

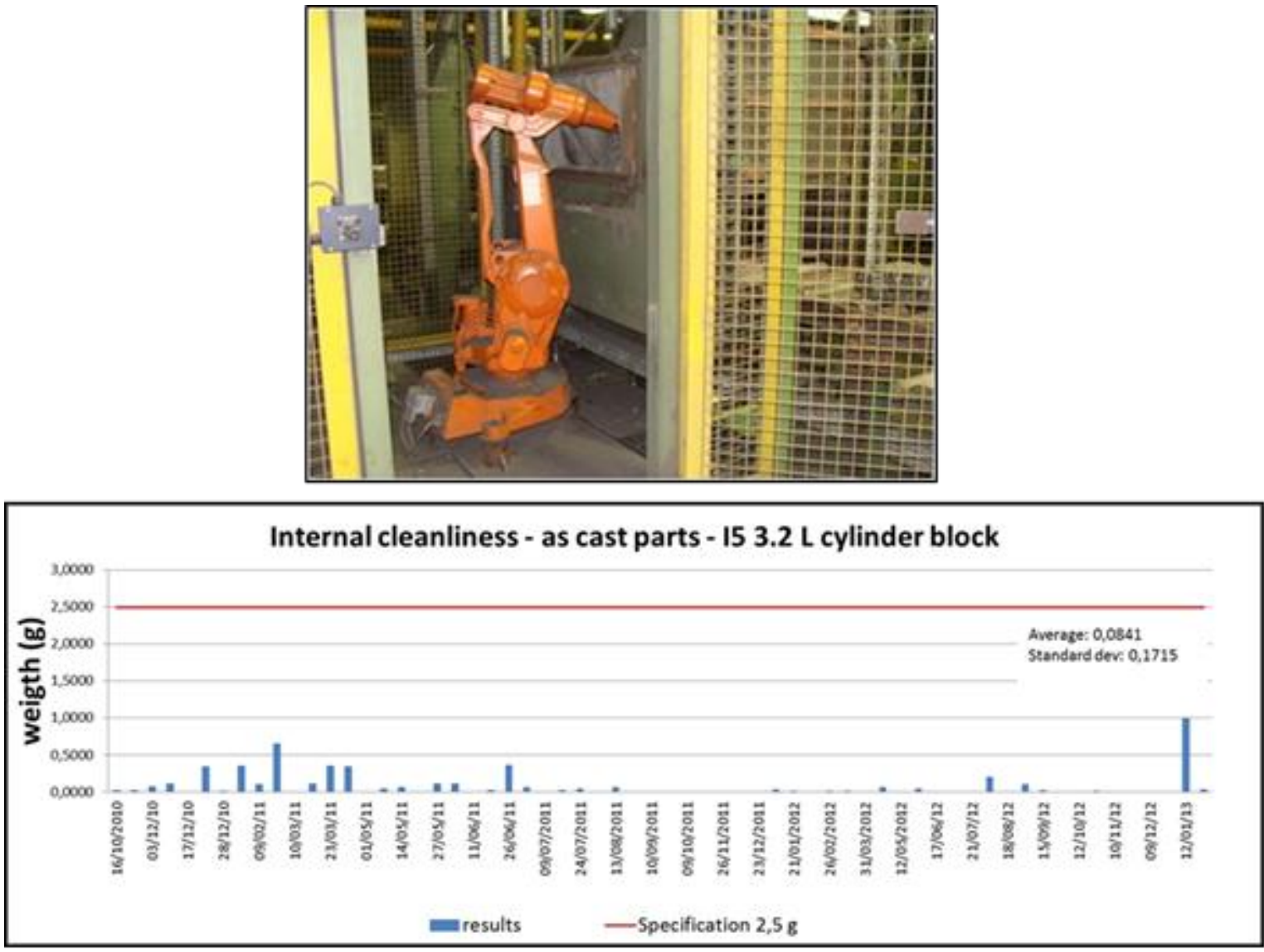

Figure 21 - Use of robot for internal cleaning of cylinder blocks and heads. The graph shows results from the test of internal cleanliness of a cylinder block.

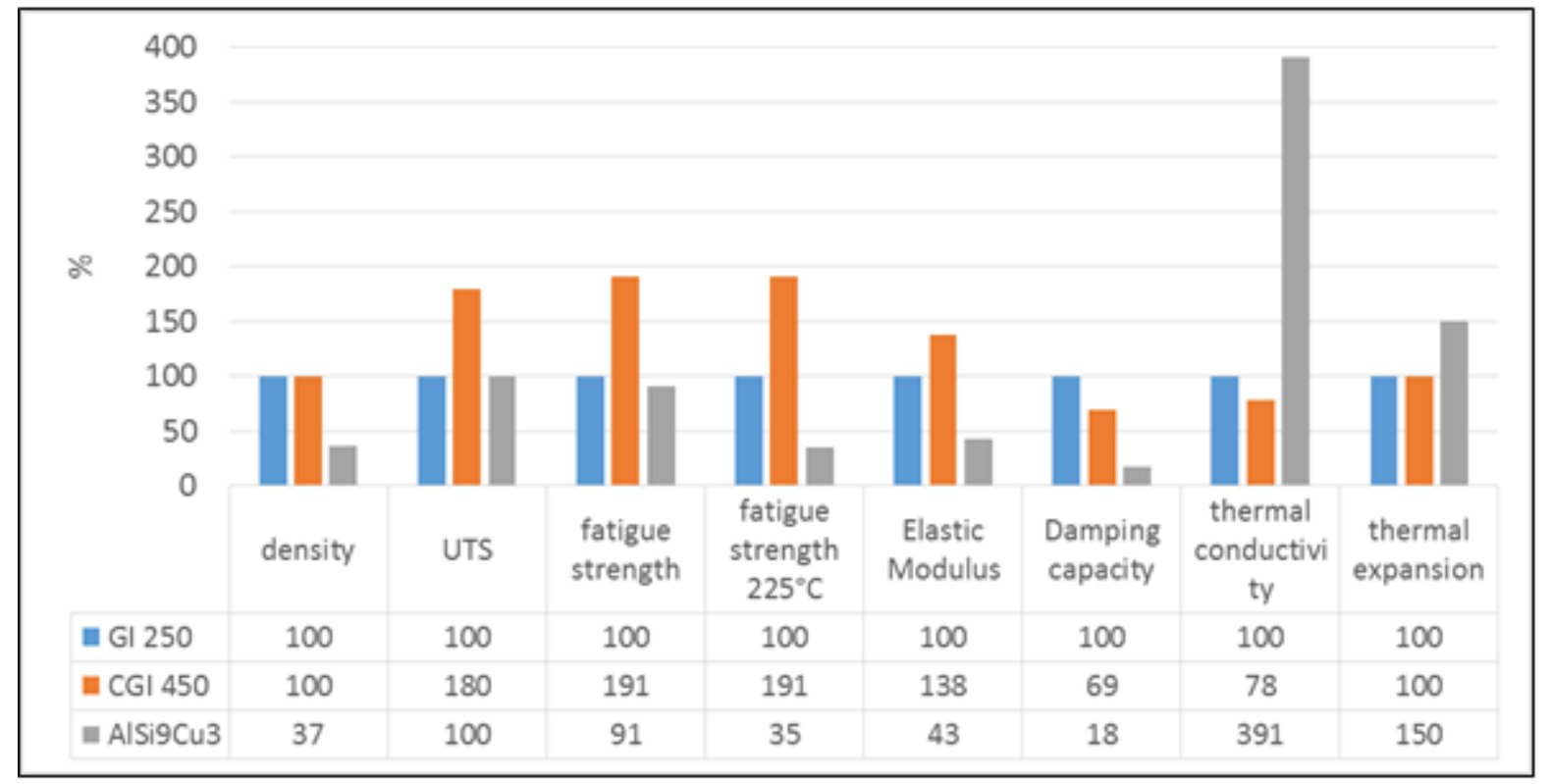

Figure 22 - Comparison of properties between gray iron, CGI and aluminum. It was adopted $100 \%$ for gray iron. Adapted from [16, 18, 24, 25, 26]. 


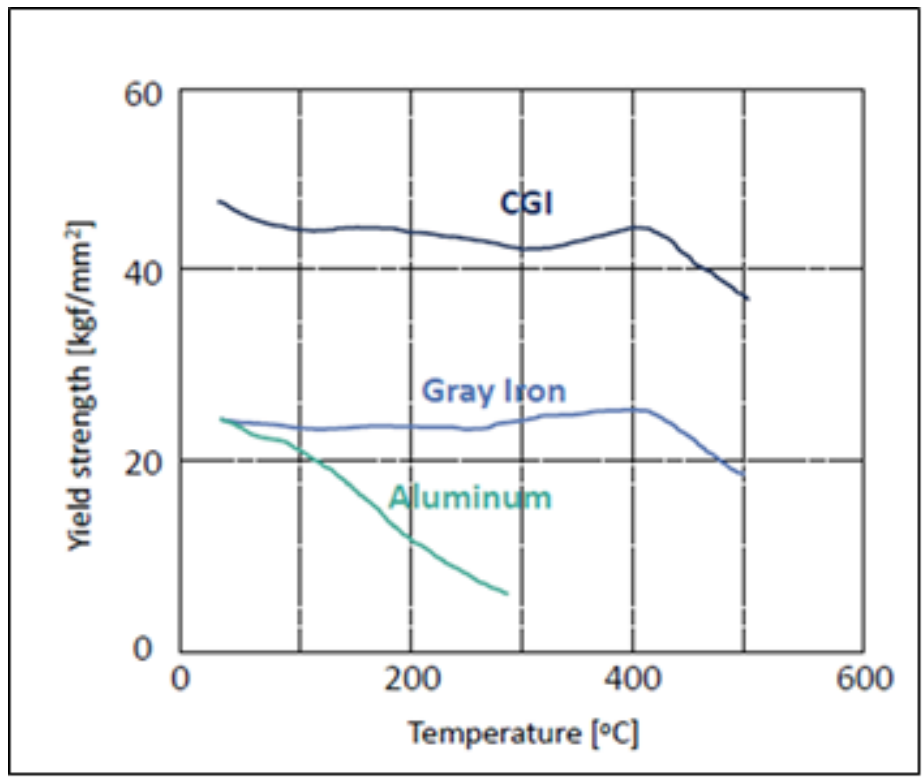

Figure 23 - Cast iron properties remain stable working on temperatures up to $400^{\circ} \mathrm{C}$ [2].

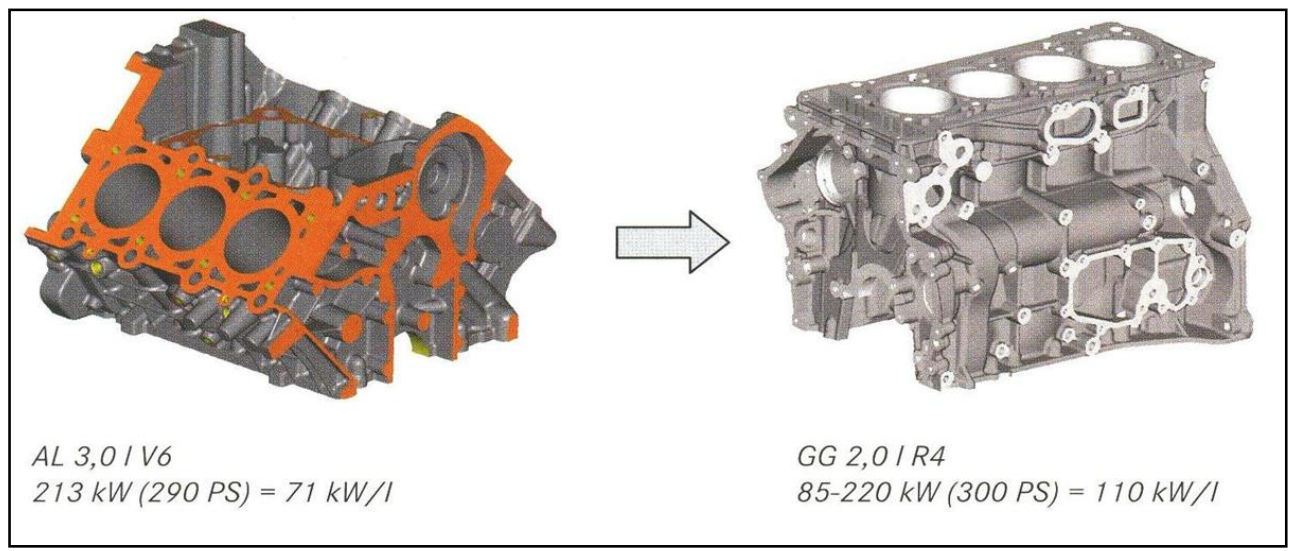

Figure 24 - Change from a V6 to an I4 cylinder block engine, with about the same power [27].

Table II shows a comparison between two engine of 1,8/2,0 L, gasoline, direct injection and turbo, Euro 6. For the power of $125-135 \mathrm{~kW}$, it was possible to design with gray iron an engine even lighter than the engine with aluminum cylinder block [28]. 
Table II - Comparison of 4 cyl engines, gasoline, with cylinder blocks in aluminum and gray iron. Injection pressure up to 200 bar. Exhaust manifold integrated in the aluminum cylinder head [28].

\begin{tabular}{|c|c|c|}
\hline & BMW & Audi \\
\hline Displacement & 2.01 & 1.81 \\
\hline Power and torque & $\begin{array}{l}135 \mathrm{~kW}(270 \mathrm{~N} . \mathrm{m}) \text { to } 180 \mathrm{~kW} \\
(350 \mathrm{~N} . \mathrm{m})\end{array}$ & 125 kW (320 N.m) \\
\hline Fuel consumption & 7,9 l/100 km (183 g CO2/km) & \\
\hline $\begin{array}{l}\text { Material of the cylinder } \\
\text { block }\end{array}$ & $\begin{array}{l}\text { AlSi9Cu3, coating in the } \\
\text { cylinders with a } 0,3 \mathrm{~mm} \text { iron } \\
\text { alloy }\end{array}$ & $\begin{array}{l}\text { Gray iron, section thickness } \\
\text { down to } 3,0 \mathrm{~mm}\end{array}$ \\
\hline engine weight & $143 \mathrm{~kg}$ & $131,5 \mathrm{~kg}$ \\
\hline
\end{tabular}

Another example is presented on figure 25, with two engines with the same displacement, power and torque, one with an aluminum cylinder block and the second with a CGI cylinder block. The higher strength of CGI allows the design of a very compact and light engine. This is a clear example of the potential of cast irons in opening opportunities for the designers (29).

Figure 25 also indicates the energy spend to produce the cylinder block, with high values for the aluminum cylinder block. More results on this can be seen on figure 26, for the production of an R6 cylinder block. Figure 26-a shows $\mathrm{CO}_{2}$ emissions in the production of the metal from the ore (primary metal) or from scrap (secondary metal). Considering the weight of the casting (figure 26-b), it was built figure 26-c, showing $\mathrm{CO}_{2}$ emissions per cylinder block, considering the most favorable situation for aluminum, using only secondary metal [30]. In practical situations it is used a mixture of primary and secondary aluminum, to dilute undesirable impurities. According to [31], it is necessary to run a car up to $400.000 \mathrm{~km}$ to get back the additional energy spend in the production of an aluminum cylinder block, compared to cast iron. These numbers can be arranged in different ways to favor one or another material, the important point is that energy and emissions must be considered when selecting a material for mass production. 


\begin{tabular}{|l|l|l|}
\hline & \\
\hline & Mercedes 3.0 L 350d & Audi 3.0 L TDI \\
\hline Cylinder block & Aluminum & CGI \\
\hline Fatigue strength - bending (MPa) & 80 & 200 \\
\hline Dimensions of the block (mm) & $520 \times 495 \times 350$ & $350 \times 460 \times 270$ \\
\hline Engine length (mm) & 565 & 440 \\
\hline Energy in the cyl block (kJ) & 4.050 & 535 \\
\hline Power (ps) / Torque (N.m) & $258 / 620$ & $272 / 600$ \\
\hline Engine weight (kg) & 208 & 193 \\
\hline
\end{tabular}

Figure 25 - Comparison of 2 engines with similar power and torque. Cylinder blocks in $\mathrm{Al}$ and in Cast Iron [29].

\section{FINAL COMMENTS:}

It was revised the trend in new engines, with increasing challenges for the foundry industry concerning geometric complexity and physical and mechanical properties. It is clear the continuing need for technological developments in materials and manufacturing processes. Cast irons and aluminum will continue to compete, each presenting technological innovations over time. Energy and emissions should be considered when comparing these materials. 


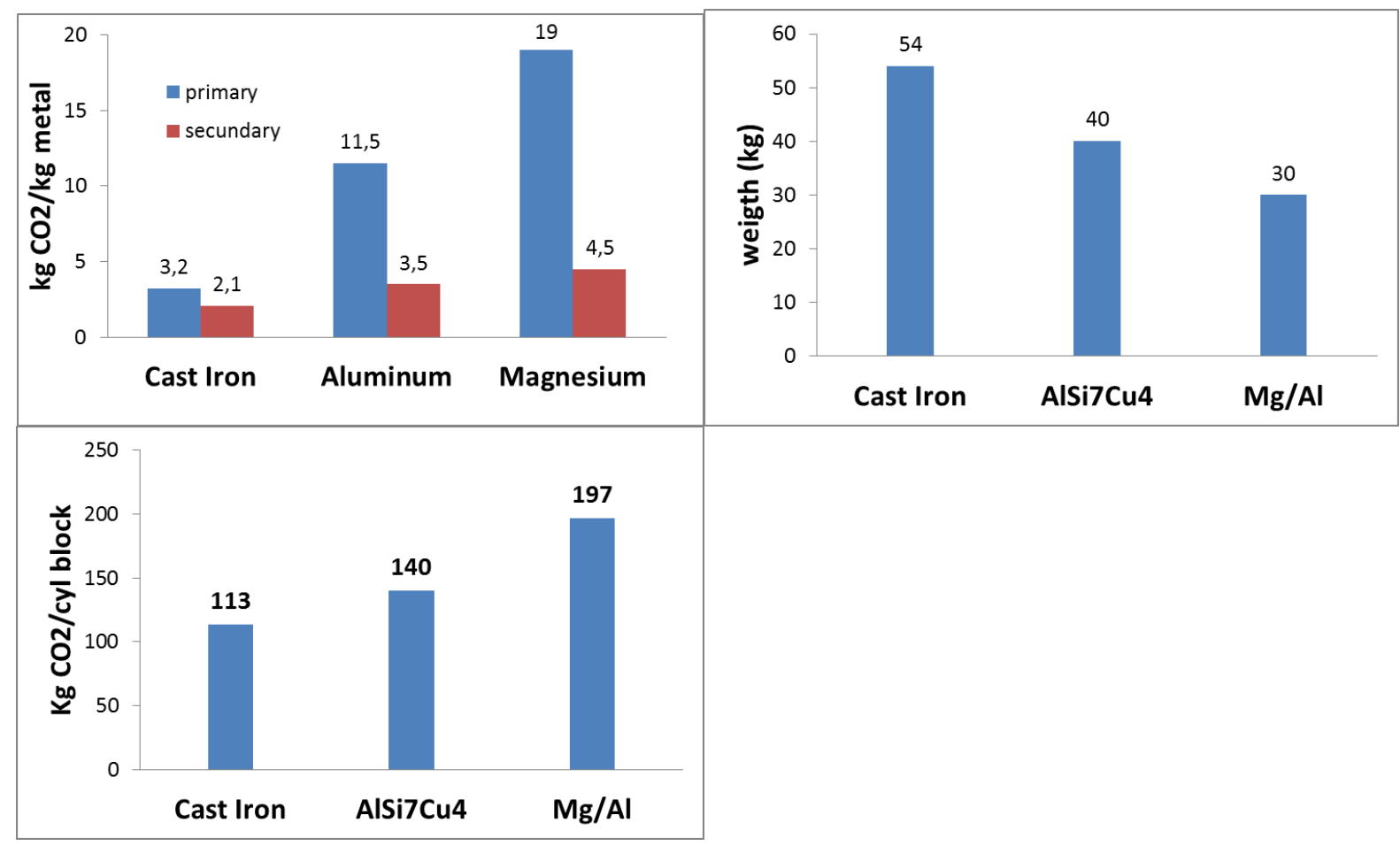

Figure $26-\mathrm{CO}_{2}$ emissions in the production of the cylinder block of the R6 BMW engine, using secondary metal [30].

\section{REFERENCES}

[1] NHTSA. CAFE Summary of Fuel Economy Performance. http://www.nhtsa.gov/fueleconomy. Website accessed on 15 Dec 2014.

[2] MARTIN, T; WEBER, R; KAISER, R.W. Dünnwandige Zylinderblöcke aus Gusseisen. Giesserei-Erfahrungsaustauch, n.8, pp. 357-362, 2003.

[3] WEGENER, R. \& GÖRTZ, W. Herstellen von hoch-komplexen Zylinderkurbelgehäusen. Giesserei, vol 102, $\mathrm{n}^{\circ}$ 1, p. 42-47, 2015.

[4] http://en.wikipedia.org/wiki/Ford_EcoBoost_engine\#mediaviewer/File:Ford_EcoBoost _1,0_Motorblock.jpg. Website accessed on 15/4/2016.

[5] SLAVNICH, D. Driven by success. Engine Technology International, 2014, p. 28-36.

[6] International Engine of The Year Awards 2015.

[7] http://en.wikipedia.org/wiki/List_of_VM_Motori_engines. Website accessed on $15 / 4 / 2016$.

[8] http://www.autoblog.com/2014/05/09/audi-details-updated-31-v6-tdi-engine. Website accessed on 15/4/2016.

[9] http://www.autonews.com/article/20130503/BLOG06/130509953\#ixzz2SFxQqr4u.

Website accessed on 15/12/2014.

[10] http://blog.caranddriver.com/audi-gives-us-the-skinny-on-its-third-gen-ea888-turbo-fourand-the-sq5\%e2\%80\%99s-twin-turbo-diesel-v6/. Website accessed on 15/12/2014.

[11] ECCLESTONE, C. 2015 F-150 To Introduce Ford's turbocharged 2.7-Liter EcoBoost V6 "Nano" Engine? http://motrolix.com/2013/12/2015-f-150-to-introduce-fordsturbocharged-2-7-liter-ecoboost-v6-nano-engine/, Website accessed on 15/12/2015. 
[12] WEISSLER, P. Ford's new 2.7-L EcoBoost V6 designed for lighter aluminum F-150. http://articles.sae.org/13388/, Website accessed on 06/12/2014.

[13] WOJDYLA, B. http://www.popularmechanics.com/cars/a12933/

engineofthemonthford27litertwinturboecoboostv616723072/ Website accessed on 20/02/2016.

[14] OLIVEIRA LIMA, F. F. \& SOARES LOPES, R. Thin wall cylinder blocks. Project Report. IPT/TUPY, 2014

[15] GUESSER, W.L; DEMETRIO, V.B; MÜLLER, A; RABELO, A. Fatigue strength of cast irons. Tupy/SENAI Project, Internal Report 2016.

[16] GUESSER, W.L \& MARTINS, L.P.R. Stiffness and vibration damping capacity of high strength cast irons. SAE International paper 2016-36-0126, 2016.

[17] GASPARIN, H; VERRAN, G. O; GUESSER, W. L; TOMIYAMA, M; JUNGES, C.E. Propriedades mecânicas a altas temperaturas de ferros fundidos cinzentos aplicados a cabeçotes de motor a diesel. ABM 69th Annual Congress, São Paulo, 2014.

[18] GUESSER, W.L; MASIERO, I; MELLERAS, E; CABEZAS, C.S. Thermal conductivity of gray iron and compacted graphite iron used for cylinder heads. Revista Materia (UFRJ), vol 10, 2005.

[19] MOCELLIN, F. Desenvolvimento de tecnologia para brunimento de cilindros de blocos de motor em ferro fundido vermicular. PhD Thesis, UFSC, Mechanical Engineering Department, 2004.

[20] SCHMID, J. Optimiertes Honverfahren für Gusseisen-Laufflächen. VDI Berichte $\mathrm{n}^{\circ}$ 1906, p. 217, 2006.

[21] RÖHRIG, K \& WERNING, H. BMW-V8-Dieselmotor - realisiert mit innovativen Konstruktionen aus Gusseisenwerkstoffen. Konstruiren + Giessen, vol 24, no 3, p. 21, 1999. [22] SCHÖFFMANN, W; LANGMAYR, F; SAUERWEIN, U; SORGER, H; ZIEHER, F.Development of engine structures for high performance diesel engines. $7^{\text {th }}$ Machining Workshop for Powertrain Materials. Darmstadt, 2004.

[23] CARLINI, E. C, GUESSER, W. L, MASIERO, I. Estudo sobre a expansão térmica das areias de fundição e a sua influência sobre as propriedades a quente dos machos. Revista Matéria (UFRJ), 2011.

[24] BICK, W; MAASSEN, F; HAUBNER, F. Leichtbaukonzepte für Dieselmotoren mit einem Spitzendruck von 200 bar. Giesserei Kompact (Giesserei), n. 1, p. 8-16, 2005.

[25] STADLER, F; ANTREKOWITSCH, H;FRAGNER, W; KAUFMANN, H;

UGGOWITZER, P J. Einfluss der Hauptlegierungselemente auf wichtige physikalische Eigenschaften warmfester AlSi-Gusslegierungen. Giesserei, vol 99, n.10, p. 100, 2012. [26] DAWSON, S \& INDRA, F. Compacted Graphite Iron - A New Material for Highly Stressed Cylinder Blocks and Cylinder Heads. 28th Int. Vienna Motor Symposium, 2007. [27] WEBER, R \& GÖRTZ, W. Gusseisen - der Werkstoff für Zylinderkurbelgehäuse der neuesten Motorengeneration. Giesserei, n³ , p. 20, 2010.

[28] GORONCY, J \& PESTER, W. Kleine Vierzylinder von Audi und BMW im Vergleich. http://www.ingenieur.de/Themen/Automobil/Kleine-Vierzylinder-Audi-BMW-im-Vergleich 04/11/2011. Website accessed on 20/4/2014.

[29] SINTERCAST. GIFA, Düsseldorf, 2015.

[30] SÉGAUD, J M. Sustainability and its effects on light weight concepts and process chains. Casting Plant \& Technology, $\mathrm{n}^{\circ}$ 2, p. 26, 2011.

[31] SOBOTA, A; GÖRTZ, W. Studie zur Energiebilanz und CO2-Emmisionen von Zylinderkurbelgehäusen aus Aluminium und Gusseisen. NewCast-Forum, GIFA, 2015. 